\section{Hydrogen Sulfide-releasing anti-inflammatory drug ATB-340 treatment potentially reduces mesenteric metaflammation in the experimental age- and high fructose dietary-induced injury}

\author{
Oleh Revenko1, Vasyl Kovalyshyn², Antonina Yashchenko², \\ John L. Wallace ${ }^{3}$, Oksana Zayachkivska ${ }^{1}$

\section{${ }^{1}$ Physiology Department of Danylo Halytskyy Lviv National Medical University, Lviv, Ukraine \\ 2 Histology, Cytology and Embryology Department of Danylo Halytskyy Lviv National Medical University, Lviv, Ukraine ${ }^{3}$ University of Calgary, Calgary, Canada}

Metaflammation (MF) is associated with visceral adiposities involved in the metabolic, cardiovascular, and gastrointestinal disease pathogenesis while their target therapeutic strategy is still limited. The link between mesenteric white adipocytes (MA) and stromal-vascular cellular remodeling in advanced age and Western diet consumption which is the base of MF remain undiscovered. Hydrogen Sulfide $\left(\mathrm{H}_{2} \mathrm{~S}\right)$-non-steroidal anti-inflammatory drugs ( $\mathrm{H}_{2} \mathrm{~S}$-NSAIDs) are a promising novel class of drugs regarding their cytoprotective, regulatory redox signaling, vasodilatory, and anti-inflammatory effects.

Aim. To study the effectiveness of novel $\mathrm{H}_{2}$ S-NSAIDs ATB-340, a hybrid compound of $\mathrm{H}_{2} \mathrm{~S}$ and aspirin (ASA) over conventional ASA, and combination of ASA and NaHS on mesenteric cellular adaptive changes in experimental age- and high fructose dietary (HFD)-induced injury.

Methods: Mesenteric subcellular adaptive responses of aged male rats on a standard diet (SD) or 4 weeks HFD that underwent acute water-immersion restraint stress (WIRS) were evaluated by electron microscopy. The effects of 9 days exogenous administration of ATB-340 (17.5 mg/kg/day), ASA (10 mg/kg/day) and sodium hydrosulfide (NaHS, $5.6 \mathrm{mg} / \mathrm{kg} /$ day) were investigated. Serum glucose level, thiobarbituric acid reactive substances (TBARS), and activities of cystathionine $\gamma$-lyase (CSE) and cystathionine $\beta$-synthase (CBS), thiosulfate-dithiol sulfurtransferase (TST), and sulfite oxidase (SO) were examined biochemically using spectrophotometry.

\section{OPEN OACCESS}

DOI: $10.25040 /$ ntsh2021.01.09

For correspondence:

69 Pekarska str., Lviv, Ukraine, 79009

E-пошта: wersus35@gmail.com

Received: Apr, 6, 2021

Accepted: May, 16, 2021

Published online: June, 29, 2021

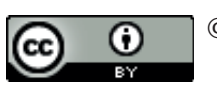

Oleh Revenko Vasyl Kovalyshyn, Antonina Yashchenko, John Wallace, Oksana Zayachkivska,

\section{ORCID IDs}

Oleh Revenko

https://orcid.org/0000-0003-0347-0406 Vasyl Kovalyshyn

https://orcid.org/0000-0003-2106-5076

Antonina Yashchenko

https://orcid.org/0000-0002-8422-5834

John L Wallace

https://orcid.org/0000-0002-4853-1682

Oksana Zayachkivska

https://orcid.org/0000-0002-4309-2473

Disclosures. Author state that there is no conflict of interest

\section{Authors Contributions:}

Concept - Oksana Zayachkivska;

Data Collection and/or Processing - Oleh Revenko, Vasyl Kovalyshyn, Antonina Yashchenko;

Writing Manuscript - Oleh Revenko, Vasyl Kovalyshyn Antonina Yashchenko;

Review and editing: Oksana Zayachkivska, John L Wallace.

Funding. This work has been supported in part by Danylo Halytsky Lviv National Medical University under the project «Role of systemic and local mechanisms in cytoprotection under the extreme influence» (the state registration ID 0116U004510) and "Investigation of integrative systems" control mechanisms in the health, functional disorders in the organism, and determine the ways of their correction» (the state registration ID 0121U100164).

Ethical approval: The bioethic committee of DH LNMU (N4, 23.04.2019)

Results: In HFD groups exposed to WIRS treatment with ATB-340 protected MA, as well their mitochondria, microvascular endothelial, and sub-endothelial structures, fibroblasts were observed vs the ASA and H2S+ASA-treated groups that had signs of endothelial dysfunction, MA damage with dysfunctional mitochondria, and mitochondria with fat incorporation. In rats fed with HFD and ASA treatment, low activities of CSE, CBS, TST and the rise of TBARS level and SO activity were observed. Treatment with ASA+NaHS, ATB-340 of aged rats lowered TBARS and enhanced $\mathrm{H} 2 \mathrm{~S}$ enzyme activities in contrast to the vehicle-treated group $(p<0.05)$.

Conclusions. Mitochondrial alterations, endothelial damage, and redox disbalance are key factors for aged rat mesenteric adipose tissue remodeling during Western diet consumption. Our 
results contributing to identifying powerful intervention by effective compound H2S-ASA, novel $\mathrm{H}_{2} \mathrm{~S}$-NSAIDs, which has the potential to modulate mesenteric metaflammation, vascular function by enhancement $\mathrm{H}_{2} \mathrm{~S}$ synthesis and redox regulatory and cytoprotective activities.

Keywords: Mesentery; white adipocytes, mitochondria; endothelial dysfunction; Hydrogen Sulfide-releasing anti-inflammatory drug (ATB-340); Hydrogen Sulfide (H2S); Thiobarbituric acid reactive substances (TBARS); Cystathionine gamma-lyase (CSE); Cystathionine beta-synthase (CBS); Thiosulfate-dithiol sulfurtransferase (TST); Sulfide oxidase (SO).

\section{OPEN OACCESS}

DOI: $10.25040 /$ ntsh2021.01.09

Для листування:

м. Львів, вул. Пекарська, 69, 79010

Е-пошта: wersus35@gmail.com

Стаття надійшла: 06.04.2021

Прийнята до друку: 16.05.2021

Опублікована онлайн: 29.06.2021

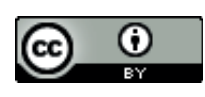

С Олег Ревенко, Василь Ковалишин, Антоніна Ященко, Джон Л Воллес, Оксана Заячківська

ORCID ID

Oleh Revenko

https://orcid.org/0000-0003-0347-0406

Vasyl Kovalyshyn

https://orcid.org/0000-0003-2106-5076

Antonina Yashchenko

https://orcid.org/0000-0002-8422-5834

John L Wallace

https://orcid.org/0000-0002-4853-1682

Oksana Zayachkivska

https://orcid.org/0000-0002-4309-2473

Конфлікт інтересів: Автори декларують, що немає конфлікту інтересів.

\section{Особистий внесок авторів:}

Концепція - Оксана Заячківська;

Збір та обробка даних - Олег Ревенко,

Василь Ковалишин, Антоніна Ященко;

Написання тексту - Олег Ревенко, Ва-

силь Ковалишин, Антоніна Ященко;

Рецензування - Оксана Заячківська,

Джон Л. Воллес;

Фінансування. Проведено у межах науково-дослідницької роботи кафедри нормальної фізіології, Львівського національного медичного університету імені Данила Галицького (Львів, Україна) за темами: «Дослідження ролі системних та паракринних регуляторних механізмів у забезпеченні гомеостатування функціонально-метаболічних параметрів організму за умов адаптації до дії екстремальних чинників різної природи» (номер державної реєстрації: 0116U004510) та «Вивчення механізмів регуляції інтегративних систем організму в умовах норми, функціональних розладів та з'ясування шляхів їх корекції» (номер державної реєстрації: 0121U100164).

Дозвіл біоетики: комітет біоетики ЛНМУ (№ 4, 23,04,2018)

\section{$\mathrm{H}_{2} \mathrm{~S}$-вивільнюючий нестероїдний протизапальний препарат АТВ-340 знижує мезентеріального метазапалення за умов старіння та пошкоджувального впливу високофруктозної дієти}

Олег Ревенко1, Василь Ковалишинаㄹ, Антоніна Ященко², Джон Л. Воллес ${ }^{3}$, Оксана Заячківська ${ }^{1}$

${ }^{1}$ Кафедра нормальної фізіології, Львівський національний медичний університет імені Данила Галицького, Львів, Україна

${ }^{2}$ Кафедра гістології, цитології та ембріології, Львівський національний медичний університет імені Данила Галицького, Львів, Україна

з Університет Калгарі, Калгарі, Канада

Метазапалення (запалення, пов'язане з метаболічними розладами), що часто асоційоване з вісцеральним ожирінням, лежить в основі патогенезу метаболічних, серцево-судинних та гастроентерологічних захворювань, проте стратегія цільового терапевтичного впливу на процес сьогодні залишається нез'ясованою. Залишаються недостатньо дослідженим взаємов'язок між ремоделюванням мезентеріальних адипоцитів (МА) і стромально-судинних клітин та метазапаленням за умов старіння організму та пошкоджувального впливу «західної дієти», що пов'язана з високовуглеводним харчуванням. Гібридні $\mathrm{H}_{2} \mathrm{~S}-$ вивільнюючі нестероїдні протизапальні препарати ( $\mathrm{H}_{2} \mathrm{~S}-\mathrm{H} 33$ ) представляють собою перспективний новий клас лікарських засобів з огляду на поєднання їх цитопротекторних, судинорозширювальних, протизапальних і регуляторних властивостей щодо окисновідновлювальних процесів.

Мета. Дослідити ефективність нових $\mathrm{H}_{2} \mathrm{~S}-\mathrm{H} П 3 П$, на прикладі АТВ-340 (гібридна сполука $-\mathrm{H}_{2} \mathrm{~S}$-аспірин) у порівняні до звичайного аспірину (ASA) і поєднання ASA та NaHS на адаптаційні зміни мезентеріальних клітин у старих щурів, що отримували високофруктозну дієту (HFD).

Методи. Мезентеріальні адаптаційні зміни на субклітинному рівні у старих самців щурів, що перебували на стан- 
дартній дієті (SD) або 4-тижневій HFD, та індукції гострого водно-імобілізаційного стресу (WIRS), оцінювали за допомогою електронної мікроскопії. Для оцінювання ефективності ATB-340 використовували дев'ятиденне в/о введення (17,5 мг/кг/день), ASA (10 мг/кг/ день) і гідросульфіда натрію (NaHS, 5,6 мг/кг/день). Концентрацію глюкози в сироватці крові, рівні реактивних субстанції тіобарбітурової кислоти (TBARS) та активність цистатіонін-ү-ліази (CSE) та цистатіонін- $\beta$-синтази (CBS), тіосульфат-дитиолсульфуртрансферази (TST) та сульфітоксидази (SO) досліджували біохімічними методами з використанням спектрофотометрії.

Результати. У групах старих щурів, які перебували HFD та отримували ATB-340, виявлено менше пошкодження мезентеріальних адипоцитів, їхніх мітохондрій, ендотеліальних та субендотеліальних структур гемокапілярів і фібробластів порівняно до груп, що отримували ASA та NaHS+ASA де встановлено ознаки ендотеліальної дисфункції, пошкодження МА та їхніх мітохондрій. У групах старих щурів з HFD встановлено низьку активність CSE, CBS, TST, збільшенням вмісту TBARS і активності SO. Введення препаратів NaHS, ATB-340 у старих щурів знижувало рівень TBARS та посилювало активність ензимів, що відповідають за синтез $\mathrm{H}_{2} \mathrm{~S}$ порівняно до контролю ( $\left.\mathrm{p}<0,05\right)$.

Висновки. Мітохондріальні зміни, ендотеліальна дисфункція та окисно-відновний дисбаланс виступають вирішальними факторами ремоделювання мезентеріальної жирової тканини у старих щурів під час пошкоджень викликаних HFD. $\mathrm{H}_{2} \mathrm{~S}-\mathrm{ASA}$ (ATB-340), як представник $\mathrm{H}_{2} \mathrm{~S}-\mathrm{H} \Pi 3$ має потенціал зменшувати мезентеріальне метазапалення за рахунок посилення синтезу $\mathrm{H}_{2} \mathrm{~S}$ та регулювання окисно-відновлювальниз процесів і цитопротекторної активності.

Ключові слова: Брижа; адипоцити; мітохондрії; ендотеліальна дисфункція; гібридний $\mathrm{H}_{2} \mathrm{~S}$-асоційований аспірин (ATB-340); гідроген сульфід $\left(\mathrm{H}_{2} \mathrm{~S}\right)$; реактивні субстанції тіобарбітурової кислоти (TBARS); цистатіон гамма-ліаза (CSE); цистатіон бета-синтаза (CBS); тіосульфат-дитиолсульфуртрансфераза (TST); сульфіт-оксидаза (SO).

Metaflammation (low-grade «sterile» inflammation related to metabolic processes) is a defining characteristic of the early event of changes in metabolic physiology which play a crucial role in the development of numerous metabolic disorders associated with obesity, type 2 diabetes (DMT2), non-alcoholic fatty liver, cardiovascular diseases as well as cancer [1-4]. Chronic overnutrition and Western diet consumption are the key links to metaflammation and insulin resistance while its implication to accelerated aging, as a basis for «inflamm-aging», still lacks evidence [5, $6,7]$. Since the recent coronavirus disease (COVID-19) pandemic outbreak has shown the dangerous outcomes of a combination of COVID-19 comorbidities related to obesity and DMT2 associated with the increased global rate of mortality among aged patients, the pathogenetic-based therapy for metabolic disorders is urgently needed $[8,9]$. Anatomical and functional changes in white adipocyte tissue during aging have been noted some time ago [10], but recently its contribution to low low-grade inflammation, mesenteric white adipocytes (MA) remodeling, and local diminished blood flow could result in various pathologies, including Crohn's disease, transmural inflammation, fibrosis [11]. Over the last 20 years, the potential of hydrogen sulfide $\left(\mathrm{H}_{2} \mathrm{~S}\right)$ for anti-inflammatory, antiradical, cytoprotective, and metabolic effects was demonstrated [12]. A growing body of evidence indicates that $\mathrm{H}_{2} \mathrm{~S}$ is unique in its ability to integrate different types of intercellular inputs and to translate them into intracellular signaling pathways responsible for pleiotropic processes [13]. However, the effect of $\mathrm{H}_{2} \mathrm{~S}$ enzymatic activities of Cystathionine $y$-lyase (CSE, EC 4.4.1.1) and Cystathionine $\beta$-synthase (CBS, EC 4.2.1.22), which act within the «transsulfuration pathway», Sulfite oxidase (SO, EC 1.8.3.1) and Thiosulfate-dithiol sulfurtransferase (TST, EC 2.8.1.5) pathways that act within the sulfide oxidation pathway and could reprogram mitochondrial bioenergetics during metaflammation is 
Праці НТШ Медичні науки

2021, Том 64, № 1 ISSN 2708-8634 (print)

Оригінальні дослідження: фундаментальні науки

still lacking. Since the experimental evidence has shown that mitochondrial dysfunction is a prominent characteristic of several metabolic pathways [14], we hypothesized that donors of $\mathrm{H}_{2} \mathrm{~S}$ synthesis could preserve mesenteric tissue and result in the improvement of experimentally-induced metaflammation in ageand dietary fructose-induced animal models associated with metabolic alteration related to mitochondrial dysfunction. Accordingly, recent reports in both preclinical and clinical studies, have a new pharmacological approach associated with promising effects of exogenous $\mathrm{H}_{2} \mathrm{~S}$ treatment and hybrid $\mathrm{H}_{2} \mathrm{~S}$-releasing non-steroidal anti-inflammatory drugs ( $\mathrm{H}_{2} \mathrm{~S}$-NSAIDs) for preventing oxidative stress, vasodilatation, anti-inflammatory potency for their gastrointestinal safety $[15,16,17]$. Despite numerous reports on the effect of metabolic toxemia during the Western diet with an overload of glycemic carbohydrates on white adipocyte tissue, there are no studies of $\mathrm{H}_{2} \mathrm{~S}$-NSAIDs efficiency in case of age-related changes and the effect of high fructose diet on the gradual loss of physiological integrity of MA and mesenteric stromal-vascular cells as in the initiation and development of metaflammation [18]. Previously discussed promising results formed the basis of this study aimed at investigating the treatment by $\mathrm{H}_{2} \mathrm{~S}$-aspirin ( $\mathrm{H}_{2} \mathrm{~S}-\mathrm{ASA}$ ) vs conventional aspirin (acetylsalicylic acid, ASA) effects on mesenteric adipocytes and stromal-vascular cells of aged rats in the context of metaflammation process related to high fructose diet (HFD).

\section{Materials and methods}

All experiments were performed on male aged Wistar rats (age $=42-46$ weeks, $N=60$ ) in compliance with the norms of laboratory animals
Proc Shevchenko Sci Soc Med Sci www.mspsss.org.ua ISSN 2708-8642 (online) 2021, Vol. 64, 1

Original research: Basic sciences

under the ARRIVE guidelines and the EU Directive 2010/63/EU for animal experiments and the local animal care committee at the Danylo Halytsky Lviv National Medical University's Ethics Committee (protocol 23/04/2018 № 4). All efforts were made to minimize animal suffering and reduce the number of animals used.

\section{Experimental Protocol}

Animals were kept under standard environmental conditions and randomly assigned to ten experimental groups $(n=6)$. Figure 1 shows the design of the study.

Rats in control groups had free access to water and were fed based on a standard diet (SD), others received a high fructose diet (HFD) for 28 days [19]. The acute stress by water-immersion restraint stress (WIRS) model was induced on the 29th day of the study to investigate adaptive reactions to acute injury [20]. The rats' initial and the final body weights were recorded by an RN 10C13U, $100 \mathrm{~g}-10 \mathrm{~kg}, \pm 5 \mathrm{~g}$ (Vaga, Kyiv, Ukraine). Rat blood glucose concentrations were measured daily after $15 \mathrm{~h}$ of fasting (18:00 - 9:00) using a glucometer (Achtung TD-4207, Munich, Germany) on a blood sample taken from the tail vein. At the end of the experiments, all rats were deprived of food for $12 \mathrm{~h}$. For euthanasia, rats were deeply anesthetized with an intramuscular injection of ketamine (60 $\mathrm{mg} / \mathrm{kg}$; Biovet, Bila Tserkva, Ukraine). Then, the blood was collected from the sacrificed animals and samples of the mesenterium tissue associated with the small intestine were resected.

Animals were subdivided into a control group with SD, and experimental groups receiving hypercaloric HFD for 28 days, with and without acute WIRS. To evaluate the efficiency of novel

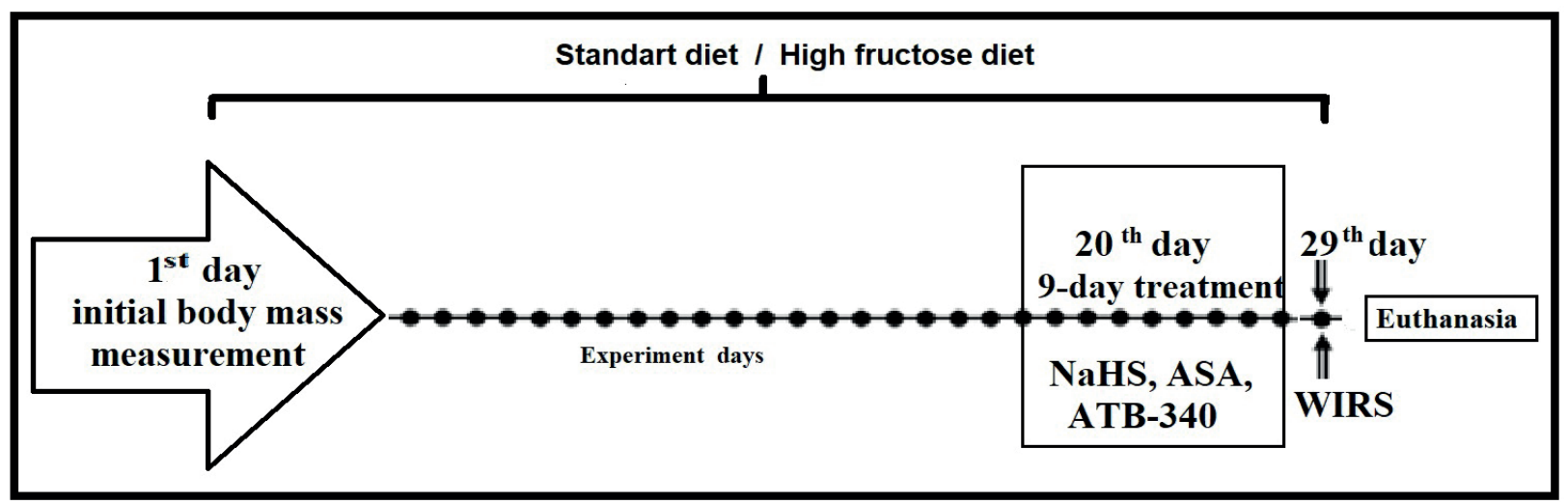

Fig.1. Study design 
$\mathrm{H}_{2}$ S-NSAID substances considered as $\mathrm{H}_{2} \mathrm{~S}$, donors were used from the 19th day of the experiment for rat treatment (during 9-days intragastrically): $\mathrm{NaHS}$ at a dose of $5.6 \mathrm{mg} / \mathrm{kg} /$ day; ASA $10.0 \mathrm{mg} / \mathrm{kg} /$ day and NaHS, $5.6 \mathrm{mg} /$ $\mathrm{kg} /$ day; ATB-340 ( $\mathrm{H}_{2} \mathrm{~S}-\mathrm{NSAIDs}$ from Antibe's drug platform, Canada) $17.5 \mathrm{mg} / \mathrm{kg} /$ day. The administration of ASA, NaHS and ATB-340 was performed in the previously tested doses [21].

The cellular and subcellular investigation via electron microscopy

For the cellular and subcellular analysis, the mesenteric material associated with the small intestine was fixed with a $2 \%$ solution of osmium oxide $\left(\mathrm{OsO}_{4}\right)$ eV $0.10 \mathrm{~mol} / \mathrm{L}$ phosphate buffer. Subsequently, mesenteric material was processed according to generally accepted methods. Ultrathin sections (30-60 nm) were made using an ultramicrotome UTMTP-3M (Sumy Electron Optics PKF, Sumy, Ukraine) and after Reynolds staining, they were photographed and examined using an electron microscope «UEMV-100K» (Sumy Electron Optics PKF, Sumy, Ukraine) for magnification by 4,000, 6,000 and 10,000 times. Histologic microphotos were examined by two experienced researchers who were unaware of the treatment. About 15 different cells in each sample were analyzed per rat.

Determining TBARS levels and CBS, CSE, SO, and TST activities

Plasma TBARS levels were evaluated by assaying a reaction with thiobarbituric acid. Lipid peroxidation products from a red-stained complex which is extracted with butanol were received. Test tubes containing serum were cooled at room temperature and maximum light absorbance was measured at $535 \mathrm{~nm}$ using a UV-visible spectrophotometer (Apel PD303, Saitama, Japan) $[19,20]$. The resected mesenteric material was washed with cold $1.15 \%$ potassium chloride solution, after which the mucous membrane was separated and homogenized in a medium of $1.15 \%$ potassium chloride in a ratio of $1: 4$. The mesenteric homogenates were centrifuged at $600 \mathrm{~g}$ and $40^{\circ}$ $C$ for 30 minutes to obtain a post-nuclear fraction. The samples of mesenteric homogenates were evaluated for catalytic activities of CBS, CSE, SO, and TST (nmol/min*1 $\mathrm{mg}$ of protein), using a modified version of the method by Stipanuk, M.H. and Beck, P.W. [22, 23].

\section{Statistical analysis}

All results were evaluated using Statistical Analysis System and visualization program Statistica 7.0 (StatSoft, Informer Technologies, Inc.) and expressed as mean \pm standard deviation for a series of experiments. A paired Mann-Whitney U-test was used for comparisons of paired treatments between two groups, and one-way ANOVA using Dunnett's test was performed to compare different experimental groups with a control group. Statistical significance was set to $p$ values $\leq 0.05$

\section{Results}

The general characteristic of all rats related to baseline and final body weights and fasting glucose levels are represented in Table 1. HFD induced changes in final body

Table 1

Changes of baseline and final body weights and fasting glucose levels under circumstances of administration ATB-340 and aspirin (ASA)-induced mesenteric injury in aged rats fed by high fructose diet (HFD) and control rats fed by standart rats (SD)

\begin{tabular}{|c|c|c|c|c|c|c|c|c|c|c|}
\hline & $\begin{array}{c}\text { SD } \\
+ \text { ASA } \\
(n=6)\end{array}$ & $\begin{aligned} & \text { SD } \\
&+ \text { ASA } \\
&+ \text { WIRS } \\
&(n=6)\end{aligned}$ & $\begin{array}{c}\text { SD+ASA } \\
+ \text { NaSH } \\
+ \text { WIRS } \\
(n=6)\end{array}$ & $\begin{array}{c}\text { SD } \\
+ \text { NaSH } \\
+ \text { WIRS } \\
(n=6)\end{array}$ & $\begin{array}{c}\mathrm{SD}+ \\
\text { ATB- } \\
340 \\
(n=6)\end{array}$ & $\begin{array}{c}\text { HFD } \\
+ \text { ASA } \\
(n=6)\end{array}$ & $\begin{array}{c}\text { HFD } \\
+ \text { ASA } \\
+ \text { WIRS } \\
(n=6)\end{array}$ & $\begin{array}{c}\text { HFD+A- } \\
\text { SA } \\
+ \text { NaSH } \\
+ \text { WIRS } \\
(n=6)\end{array}$ & $\begin{array}{c}\text { HFD } \\
+ \text { NaHS } \\
+ \text { WIRS } \\
(n=6)\end{array}$ & $\begin{array}{c}\text { HFD } \\
\text { ATB- } \\
340 \\
(n=6)\end{array}$ \\
\hline $\begin{array}{c}\text { Baseline body weight } \\
\text { (g) }\end{array}$ & $\begin{array}{l}252 \\
\pm 28\end{array}$ & $\begin{array}{l}253 \\
\pm 25\end{array}$ & $\begin{array}{l}256 \\
\pm 26\end{array}$ & $\begin{array}{l}256 \\
\pm 22 \\
\end{array}$ & $\begin{array}{l}256 \\
\pm 2\end{array}$ & $\begin{array}{l}254 \\
\pm 30 \\
\end{array}$ & $\begin{array}{l}254 \\
\pm 23\end{array}$ & $\begin{array}{l}257 \\
\pm 23\end{array}$ & $\begin{array}{l}256 \\
\pm 27\end{array}$ & $\begin{array}{l}258 \\
\pm 25\end{array}$ \\
\hline $\begin{array}{c}\text { Final body weight } \\
\text { (g) }\end{array}$ & $\begin{array}{l}277 \\
\pm 28 \\
\end{array}$ & $\begin{array}{l}280 \\
\pm 24 \\
\end{array}$ & $\begin{array}{l}277 \\
\pm 25 \\
\end{array}$ & $\begin{array}{l}275 \\
\pm 18 \\
\end{array}$ & $\begin{array}{l}275 \\
\pm 19 \\
\end{array}$ & $\begin{array}{l}451 \\
\pm 32 \\
\end{array}$ & $\begin{array}{l}457 \\
\pm 22 \\
\end{array}$ & $\begin{array}{l}452 \\
\pm 34 \\
\end{array}$ & $\begin{array}{l}455 \\
\pm 28 \\
\end{array}$ & $\begin{array}{l}451 \\
\pm 14 \\
\end{array}$ \\
\hline $\begin{array}{l}\text { Baseline fasting glu- } \\
\text { cose }(\mathrm{nmol} / \mathrm{L})\end{array}$ & $\begin{array}{c}6,5 \\
\pm 0,3 \\
\end{array}$ & $\begin{array}{r}6,7 \\
\pm 0,3 \\
\end{array}$ & $\begin{array}{r}6,5 \\
\pm 0,2 \\
\end{array}$ & $\begin{array}{c}6,5 \\
\pm 0,3 \\
\end{array}$ & $\begin{array}{c}6,6 \\
\pm 0,3 \\
\end{array}$ & $\begin{array}{c}6,5 \\
\pm 0,3 \\
\end{array}$ & $\begin{array}{c}6,5 \\
\pm 0,3 \\
\end{array}$ & $\begin{array}{c}6,5 \\
\pm 0,4 \\
\end{array}$ & $\begin{array}{c}6,6 \\
\pm 0,4 \\
\end{array}$ & $\begin{array}{c}6,4 \\
\pm 0,4 \\
\end{array}$ \\
\hline $\begin{array}{l}\text { Final fasting glucose } \\
(\mathrm{nmol} / \mathrm{L})\end{array}$ & $\begin{array}{c}6,7 \\
\pm 0,4\end{array}$ & $\begin{array}{c}6,8 \\
\pm 0,4\end{array}$ & $\begin{array}{c}6,7 \\
\pm 0,3\end{array}$ & $\begin{array}{c}6,7 \\
\pm 0,4\end{array}$ & $\begin{array}{c}6,6 \\
\pm 0,4\end{array}$ & $\begin{array}{c}8,4 \\
\pm 0,7\end{array}$ & $\begin{array}{c}8,6 \\
\pm 0,6\end{array}$ & $\begin{array}{c}8,4 \\
\pm 0,4\end{array}$ & $\begin{array}{c}8,3 \\
\pm 0,6\end{array}$ & $\begin{array}{c}8,2 \\
\pm 0,7\end{array}$ \\
\hline
\end{tabular}


Праці НТШ Медичні науки

2021, Том 64, № 1 ISSN 2708-8634 (print)

Оригінальні дослідження: фундаментальні науки

weight and final fasting glucose but we did not find significant differences vs animals fed with SD.

\section{Electron Microscopy of mesenteric adi- pocytes and endothelial changes in aged rats fed with HFD and NaHS and ATB 340 treatment}

Transmission electron microscopic studies of aged rat mesenteric material fed with SD demonstrated typical white monovacuolar adipocytes with microvessels, fibroblasts (Figure 2). The endothelial cell has an increased elongated nucleus with invaginations of the nuclear membrane, intact microvilli and blood cell in the lumen (Figure $2 \mathrm{~A}$ ), and connective tissue of the mesentery fibroblast with collagen fibers (Figure 2 B). High-magnification electron micrographs of mesenteric adipocytes from rats fed with HFD and aspirin treatment showed partly degenerated hypertrophic fat drop and plenty of defective ringlike mitochondria in the cytoplasm (Figure 3 A). Rats fed with HFD showed stress with the treatment of aspirin white adipocytes were degenerative with small fat drops, defective ring-like mitochondria, and lipid-laden phagolysosomes in the peripheral cytoplasm (Figure $3 \mathrm{~B}$ ). In rats fed with HFD exhibiting WIRS (Figure 4) with the treatment of aspirin mesenteric white adipocytes were hypertrophic and degenerative with plenty of smallest
Proc Shevchenko Sci Soc Med Sci www.mspsss.org.ua ISSN 2708-8642 (online) 2021, Vol. 64, 1

Original research: Basic sciences

light electronic density fat droplets in peripheral cytoplasm (Figure $4 \mathrm{~A}$ ), fibroblasts with vacuolation of the fibroblast's cytoplasm, and incorporated lipid droplets (Figure $4 \mathrm{~B}$ ). High-magnification electron micrographs showed their capillaries exhibiting congestion (see deformed capillary lumens), associated with perivascular and inter-stromal edema (arrows) with many microvilli (Figure $4 \mathrm{C}$ ). After the administration of aspirin with NaHS, the donor of $\mathrm{H} 2 \mathrm{~S}$ synthesis was considered, the mesenteric white monovacuolar adipocyte had few lipid droplets at the periphery of the cellular cytoplasm and a large adipose vacuole devoid of the membrane (arrow). After treatment of ATB-340, the well-preserved nucleus between two white monovacuolar adipocytes showed the internalization of free lipid derived from the degenerating adipocytes, and the well-preserved capillary was between three white monovacuolar adipocytes with single lipid droplets.

\section{Effect of NaHS, ATB 340 on TBARS levels and modulate activities of CBS, CSE, SO, and TST}

Since age and HFD-induced metaflammation is characterized by the development of oxidative injury, we determine the relevance of our histological subcellular findings in mesenterial material by the investigation of TBARS (Figure 5).
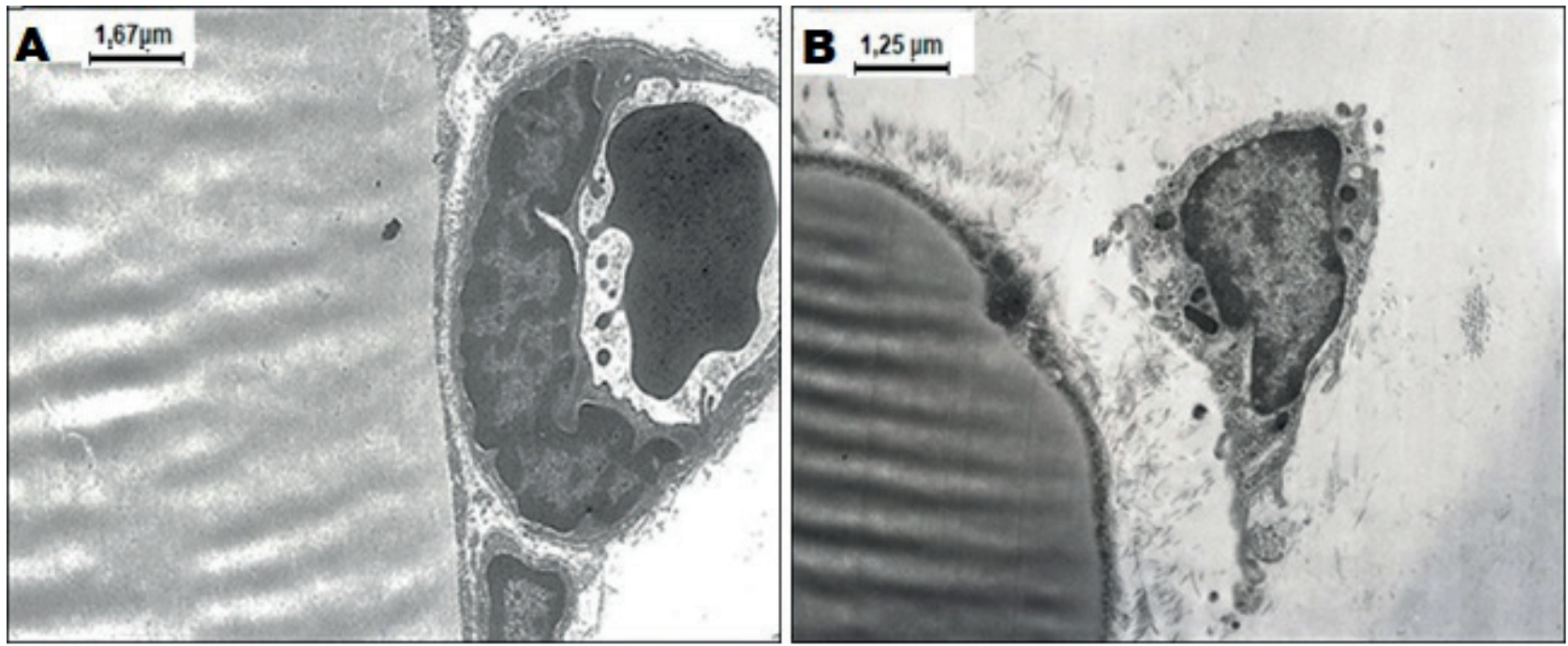

Fig. 2. Representative pictures of ultrastructural examination of mesenteric material harvested from the area associated with the rat's small intestine of aged animals on a standard diet and aspirin treatment. A: The fragment of the typical white monovacuolar adipocyte with the connective tissue of the mesentery with the presence of belonged hemocapillary with the endothelial cells with increased elongated nucleus with invaginations of the nuclear membrane and red blood cell in its lumen (original magnification $\times 6000$ ). B: A fibroblast with collagen fibers belonged to adipocyte (original magnification $\times 8000$ ) 

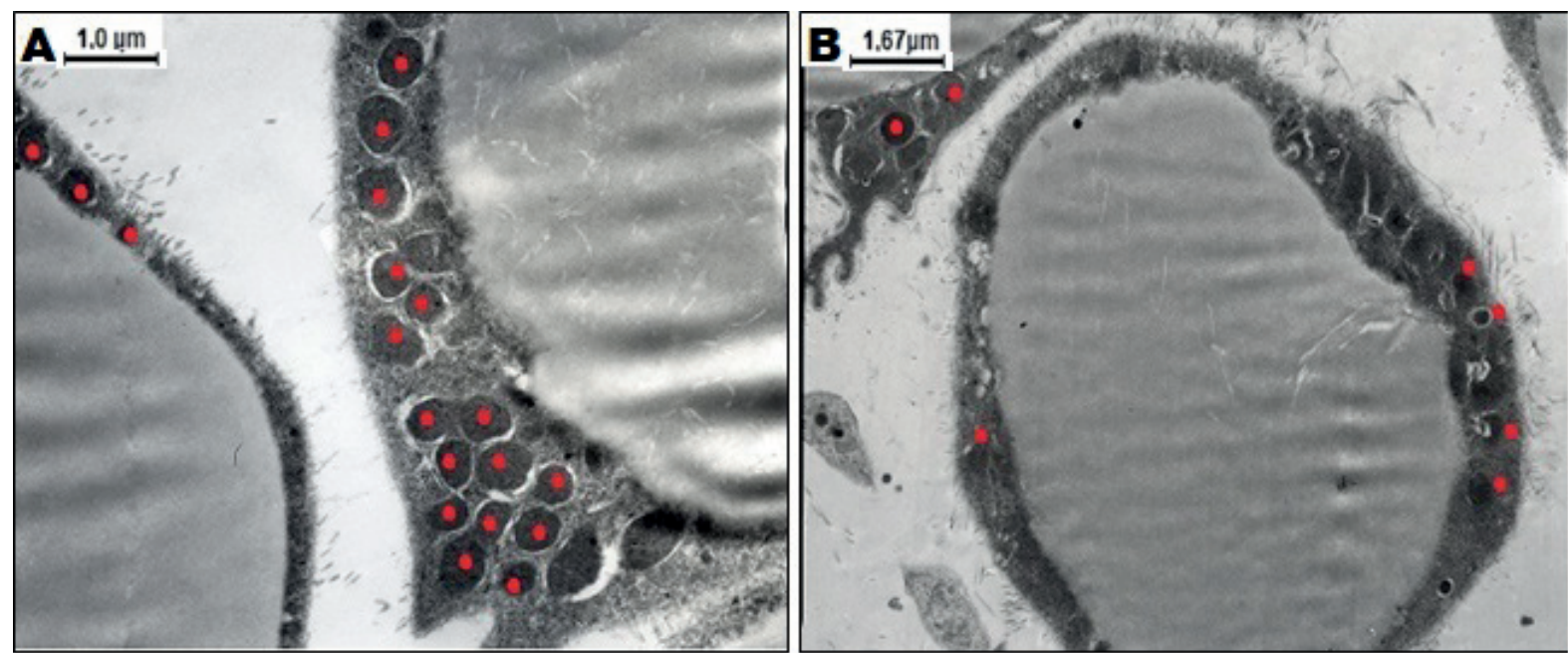

Fig. 3. Representative pictures of the effect of fructose diet and stress induction on ultrastructural examination of mesenteric material harvested from the area associated with the small intestine of aged rats with aspirin treatment $(A)$ and exhibiting acute stress (B). A: Fragment of adipocyte with defective (ring-like) mitochondria (original magnification $\times 10000$ ); B: Many smaller peripheral lipid droplets and lipid-laden phagolysosomes (arrows) are present in the marginal cytoplasm of adipocytes with defective mitochondria (original magnification $\times 6000$ ). Red dots mark ring-like mitochondria
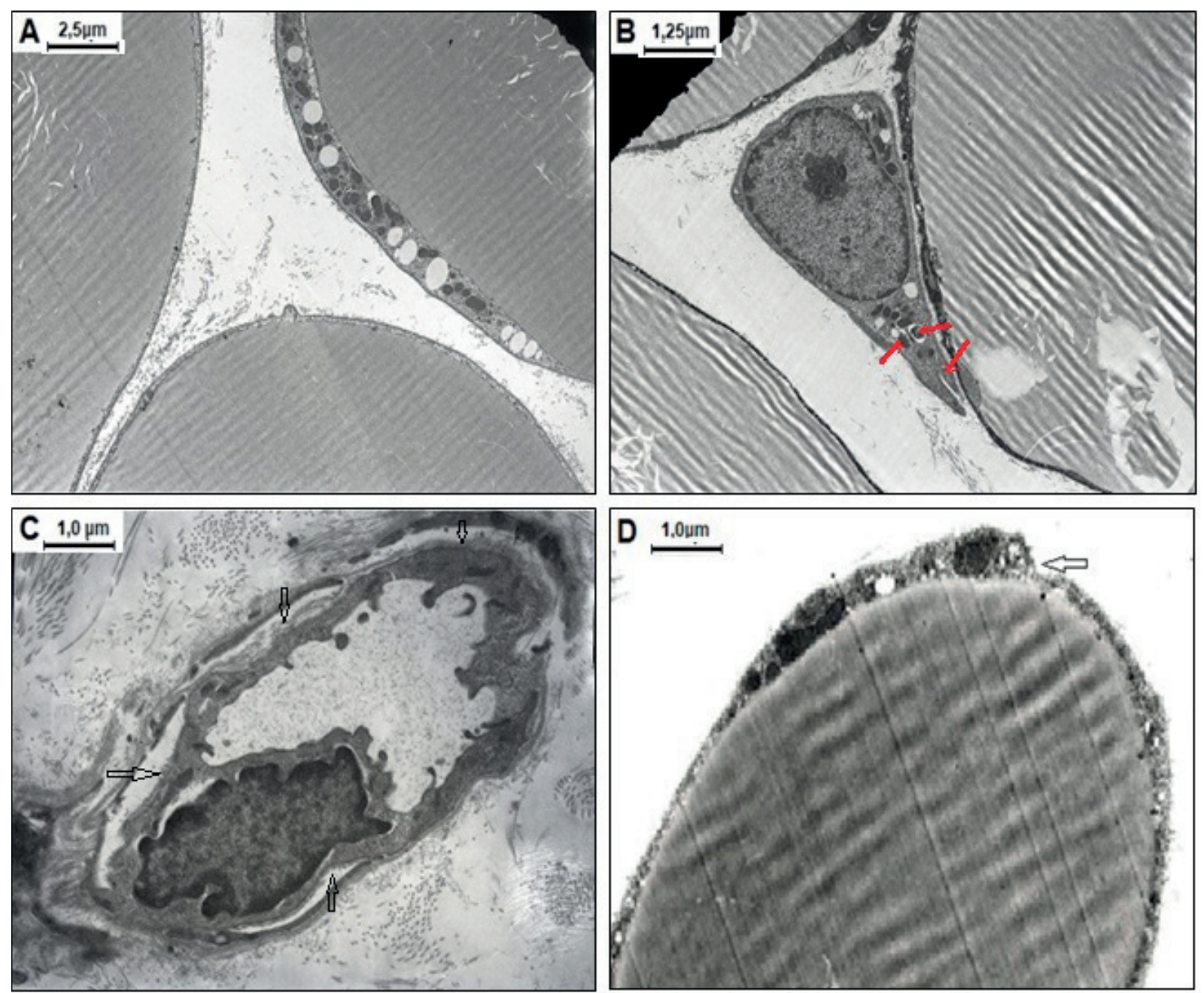

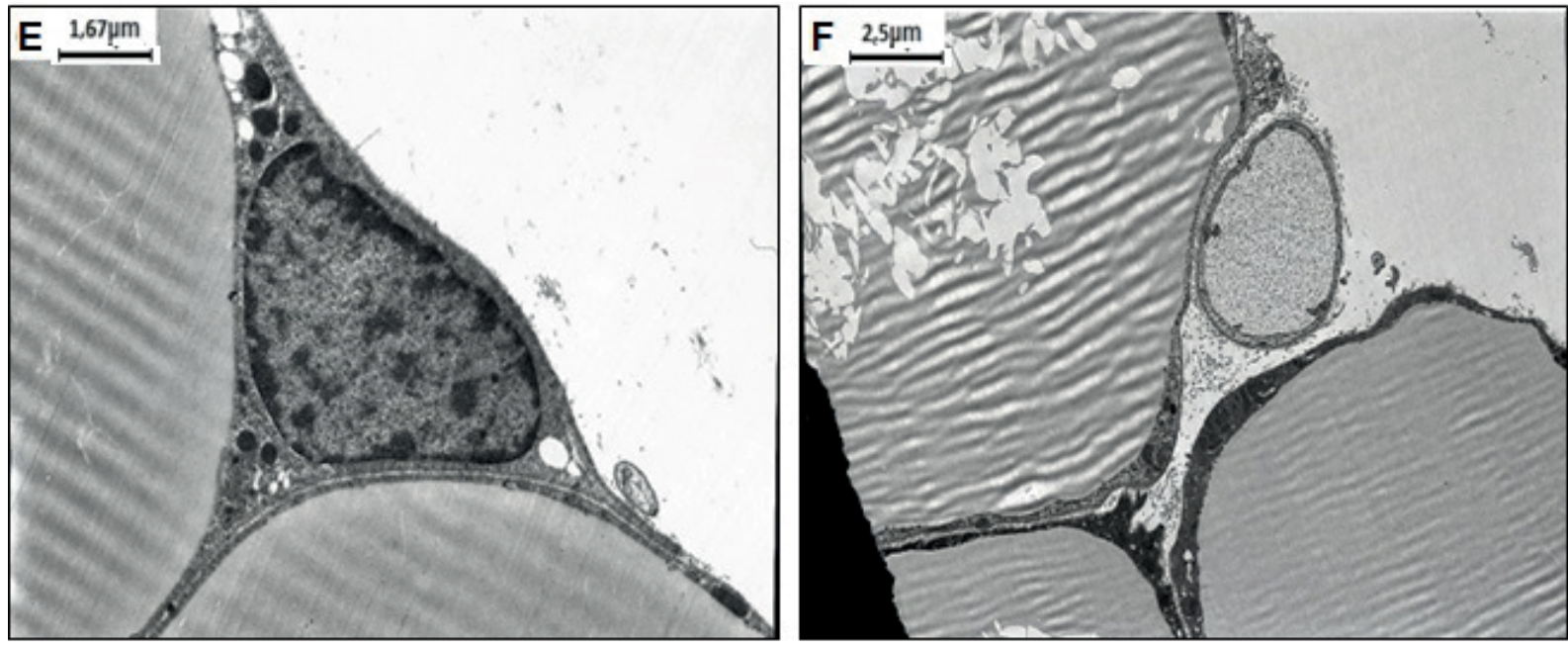

Fig. 4. Representative pictures of the effect of aspirin (A-C), the combination of aspirin and NaHS (D), and ATB-340 $(\mathrm{G}-\mathrm{H})$ on the ultrastructural changes of mesenteric material harvested from the area associated with the small intestine of aged rat on a high fructose diet and exposed to stress

A: The ultrastructure of fragments of three typical white adipocytes with evidence of fat fragmentation with the formation of several small fat drops and detective mitochondria in the cytoplasm (original magnification $\times 4000$ ).

B: A fibroblast with vacuolation of the fibroblast cytoplasm and lipid droplets released from the degenerating adipocyte (original magnification $\times 8000$ ).

C: The blood capillary belonged to adipocyte, the capillary basal membrane was uneven, fuzzy contoured, the endothelial cell had enlarged nucleus, the perivascular and inter-stromal edema is present (arrows), the collagen fibers in the perivascular space (original magnification $\times 10000$ ).

D: A typical white monovacuolar adipocytes with lipid droplets at the periphery of the cell and a large adipose vacuole devoid of the membrane (arrow).

$\mathrm{E}$ : The well-preserved nucleus of white monovacuolar adipocytes with the internalization of free light electronic density fat droplets (original magnification $\times 6000$ ).

F: The well-preserved capillary between three white monovacuolar adipocytes with single lipid droplets (original magnification $\times 4000$ )

In groups of aged rats fed with SD and treated by ASA, the TBARS content was $4.37 \pm 0.25 \mu \mathrm{M} / \mathrm{L}$ $(p<0.01)$. In HFD-fed rats treated by ASA, the levels of TBARS increased by $11.6 \%$ in aged groups $(4.88 \pm 0.17 \mu \mathrm{M} / \mathrm{L})$ in comparison to the results of SD-fed groups $(p<0.05)$. The effect of WIRS caused changes in the content of TBARS in rats treated ASA and fed HFD TBARS was significantly increased $56 \%$ (up to $7.64 \pm 0.26$ $\mu \mathrm{M} / \mathrm{L})$. It was also found that administration of NaHS, ASA with NaHS, and ATB-340 in rats, exposed to stress significantly reduced TBARS. Quantitative measurement of effect of ATB-340 demonstrated decreased in 32\% ( $p<0.05)$ vs ASA+HFD fed group. It could be interpreted as an anti-oxidative effect of ATB-340.

To further understand the efficiency of ATB-340 in comparison to conventional aspirin or $\mathrm{H}_{2} \mathrm{~S}$ donor NaHS and their combination, in metaflammation injury, the expressions of CBS, CSE TST and SO activities involved in endogenous

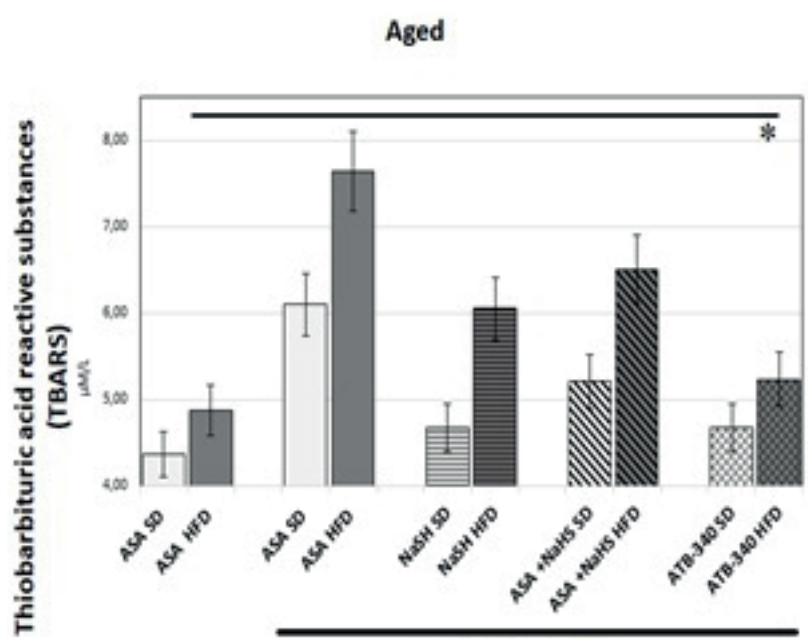

STRESS

Fig. 5 TBARS levels in aged rats fed with a standard diet (SD) or high fructose diet (HFD) without and with H2S releasing therapy (NaHS, ASA and ATB-340) and induction of acute stress $(n=6) ;(p<0.05)$ vs SD fed groups 
Праці НТШ Медичні науки

2021, Том 64, № 1 ISSN 2708-8634 (print)

оригінальні дослідження: фундаментальні науки

$\mathrm{H}_{2} \mathrm{~S}$ signaling were investigated (Fig. 6 and 7). In aged rats on SD and ASA treatment, the activities of CBS, CSE, TST and SO were reaching $0.81 \pm 0.06 \mathrm{nmol} / \mathrm{min} \times 1 \mathrm{mg}$ of protein, $1.1 \pm 0.07 \mathrm{nmol} / \mathrm{min} \times 1 \mathrm{mg}$ of protein $1.0 \pm 0.04$ $\mathrm{nmol} / \mathrm{min} \times 1 \mathrm{mg}$ of protein, and $3.61 \pm 0.1 \mathrm{nmol} /$ $\min \times 1 \mathrm{mg}$ of protein, respectively. In animals on ASA treatment and fed with HFD exposed to WRIS, enzyme activities were decreased (CBS, CSE, TST) and increase SO activity in rats compared to SD-fed rats. Aged rats on HFD had much lower activity of CBS - 53\%, CSE $55 \%$, TST $-29 \%$, and SO - 31\% compared to SD group $(p<0.05)$. In contrast, the expression of CBS, CSE, and TST showed a tendency to decrease in the aged rats on HDF, they have lower enzyme activities of CBS, CSE, and TST versus aged rats on SD. Notably, the increased activities of all $\mathrm{H}_{2} \mathrm{~S}$-related enzymes during induction WIRS were recorded, except SO, which decreased (Fig. 7 A, B). We found, that in rats exposed to stress on HFD, the efficiency of treatment by ATB-340 was similar to NaHS. These results indicate that ATB-340 has the potential for regulating redox dysbalance in rats during mesenteric injury induced by aging and HFD.

\section{Discussion}

In recent years, the importance of visceral white adipocyte tissue was revealed, with their functional roles depending on their location, cellular composition, humoral mediators (adipokines, cytokinins) [24]. The etiology of
Proc Shevchenko Sci Soc Med Sci www.mspsss.org.ua ISSN 2708-8642 (online) 2021, Vol. 64, 1 Original research: Basic sciences

obesity is still not fully elucidated, but it involves a complex interaction between environmental, host genetic, metabolic and uncontrolled immune-derived factors that are responsible for metaflammation. Mesenteric white adipocyte remodeling has the potential to produce inflammatory mediators such as adipokines, cytokines TNF-a, IL-6, and IL-1 hereby increasing tissue destruction and inducing inflammation even more in local tissues, but the whole understanding of the link of its remodeling and metaflammation is still incomplete $[25,26]$. Studies in vivo rodent models based on high fructose diet have contributed significantly to our understanding of the molecular events involved in remodeling of white adipocytes and metaflammation and their outcomes [27]. We found that in aged rats fed with 28-day HFD of mesenteric adipocyte tissue remodeling demonstrated histological changes: degenerative adipocytes containing detective mitochondria, vessels with perivascular edema, and fibroblasts with incorporated fat drops. Recent advances in understanding the role of mitochondria in numerous physiological processes, including energy supply, excess of reactive oxygen species, oxidative stress, and $\mathrm{H}_{2} \mathrm{~S}$ signaling, indicate their important role in metaflammation $[28,29]$. Decreased bioavailability of $\mathrm{H}_{2} \mathrm{~S}$ during less catalytic activities of CBS, CSE, and TST promotes changes in the endotheliocytes toward a vasoconstrictive and pro-in-
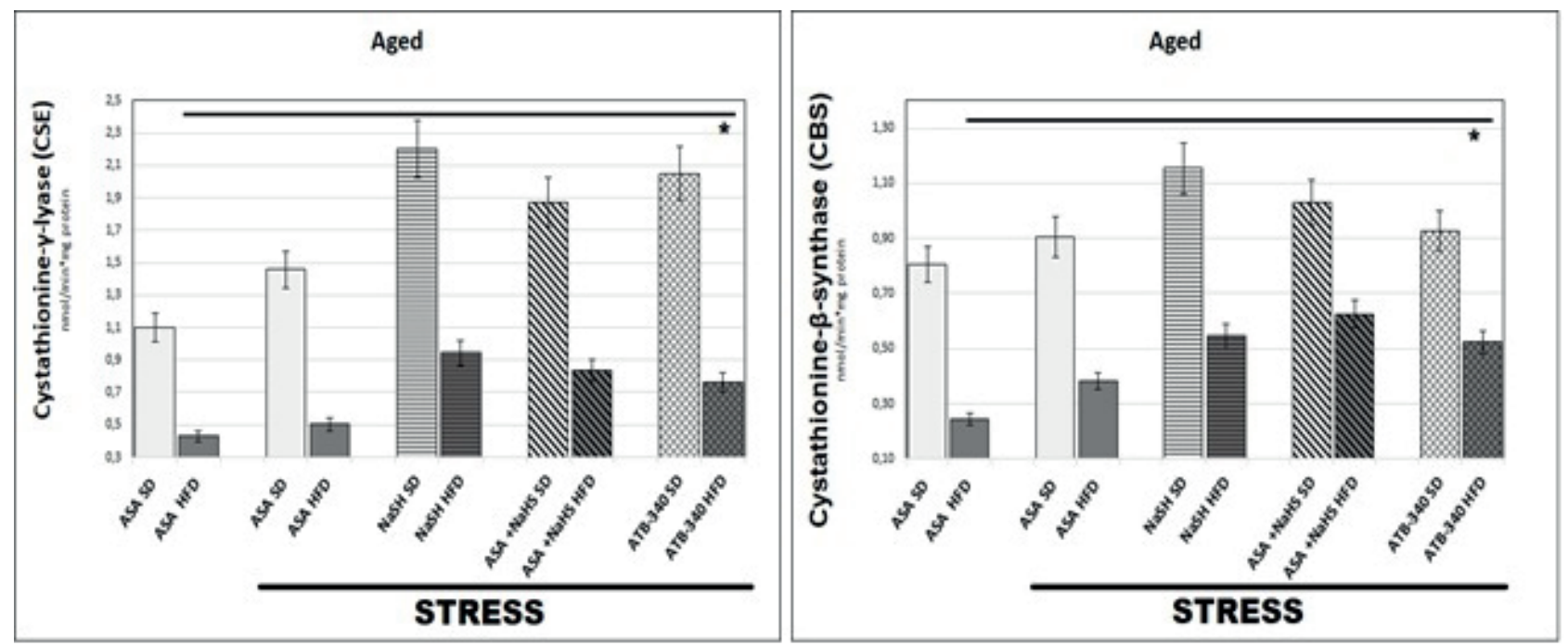

Fig. 6. Activities of Cystathionine- $\beta$-synthase (CBS), Cystathionine- $\gamma$-lyase (CSE) in aged rats $(n=6)$ fed with a standard diet (SD) or high fructose diet (HFD) without and with $\mathrm{H}_{2} \mathrm{~S}$ releasing molecule compound therapy (NaHS, ASA, and ATB-340) and induction of acute stress ( $p<0.05)$ vs SD fed group 

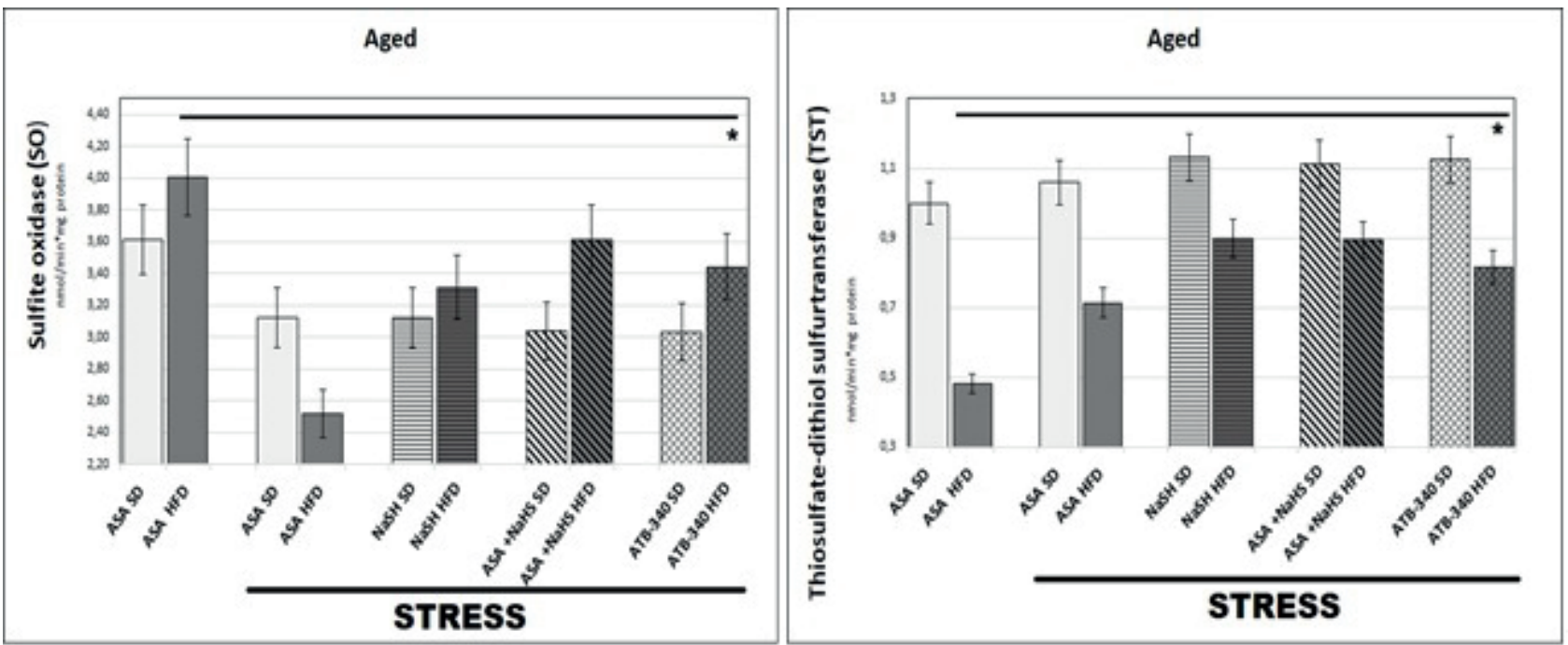

Fig. 7. Activities of Sulfide Oxidase (A, B) and Thiosulfate-dithiol sulfurtransferase (TST) (C, D) in adult (A, C) and aged rats $(B, D)(n=6)$ fed with a standard diet (SD) or high fructose diet (HFD) without and with $\mathrm{H}_{2} S$ releasing molecule compound therapy (NaHS, ASA and ATB-340) and induction of acute stress; $(p<0.05)$ vs SD fed groups

flammatory state. Several current clinical and experimental studies showed the prominent effects of $\mathrm{H}_{2} \mathrm{~S}$-NSAIDs mostly based on potent anti-oxidant, anti-inflammatory, and regulatory redox system influences which are essential to maintain metabolic homeostasis and dysregulated visceral adipocytes [30, 31, 32]. These observations led us to speculate that novel $\mathrm{H}_{2} \mathrm{~S}$-NSAIDs may induce cytoprotective and mitoprotective effects. Even though we found a significant difference in ultrastructural signs of MA mitochondrial injury in the experimental metaflammation model, during the administration of $\mathrm{H}_{2} \mathrm{~S}$ donors, the detective mitochondria in MA were lower. Our findings are in agreement with the latest studies in the pathogenesis of obesity, which have recently shown the impairment of endogenous $\mathrm{H}_{2} \mathrm{~S}$ signaling $[33,34]$. Besides, our finding of novel $\mathrm{H}_{2} \mathrm{~S}$-NSAIDs ATB-340 anti-oxidant effects related to decreased TBARS and modulation activities of $\mathrm{H}_{2} \mathrm{~S}$ enzymes will enhance understanding of their bioregulatory role on redox balance, underlying molecular mechanisms of metaflammation during aging and overload by high caloric fructose based diet [35], as well as will helpful for the discovery of novel therapeutic strategy able to ameliorate metaflammation. These findings were confirmed by transmission electron microscopic studies of efficiency ATB-340 on mesenteric adipocyte remodeling, as well as mitoprotective and cytoprotective effects on the mesenteric stro- mal-vascular cells and decreased metaflammation. To sum up, the present study is the first demonstration of the role of aging and overload of fructose as a driving force of mesenteric adipose tissue maladaptive responses which contribute to metaflammation and efficiency of $\mathrm{H}_{2} \mathrm{~S}$-aspirin in its ameliorating. Mitochondrial alterations, endothelial and fibroblastic damage, and redox disbalance are key factors for aged rat mesenteric adipose tissue remodeling during HFD injury. $\mathrm{H}_{2} \mathrm{~S}-\mathrm{ASA}$, novel $\mathrm{H}_{2} \mathrm{~S}$-NSAIDs have the potential to modulate mesenteric metaflammation by enhancement $\mathrm{H}_{2} \mathrm{~S}$ synthesis and redox regulatory and cytoprotective activities.

Future perspectives: These findings may contribute to a better understanding of the cellular/molecular mechanisms of mesenteric adipose remodeling pathogenesis, and provide new targets for the treatment of these disorders.

\section{Acknowledgments}

The authors would like to thank Zaichko N., MD, PhD, DSc (National Pirogov Memorial Medical University, Vinnytsia, Ukraine) for her expert suggestions for biochemical studies. 


\section{References}

1. Scheja L, Heeren J. The endocrine function of adipose tissues in health and cardiometabolic disease. Nature reviews endocrinology. 2019 Sep;15(9):507-24.

2. Singh P, Rai SN. Factors affecting obesity and its treatment. Obesity Medicine. 2019 Dec 1;16:100140.

3. Zhu Q, Glazier BJ, Hinkel BC, Cao J, Liu L, Liang C, Shi H. Neuroendocrine regulation of energy metabolism involving different types of adipose tissues. International journal of molecular sciences. 2019 Jan;20(11):2707.

4. Li Z, Hardij J, Bagchi DP, Scheller EL, MacDougald OA. Development, regulation, metabolism and function of bone marrow adipose tissues. Bone. 2018 May 1;110:134-40.

5. Salvestrini V, Sell C, Lorenzini A. Obesity may accelerate the aging process. Frontiers in endocrinology. 2019 May 3;10:266.

6. Wronska A, Kmiec Z. Structural and biochemical characteristics of various white adipose tissue depots. Acta physiologica. 2012 Jun;205(2):194-208.

7. Roeb E, Weiskirchen R. Fructose and non-alcoholic steatohepatitis. Frontiers in Pharmacology. 2021 Feb $8 ; 12: 47$.

8. Do TT, Marie G, Héloïse D, Guillaume D, Marthe M, Bruno F, Marion B. Glucocorticoid-induced insulin resistance is related to macrophage visceral adipose tissue infiltration. The Journal of steroid biochemistry and molecular biology. 2019 Jan 1;185:150-62.

9. Hussain A, Mahawar K, Xia Z, Yang W, Shamsi EH. Obesity and mortality of COVID-19. Meta-analysis. Obesity research \& clinical practice. $2020 \mathrm{Jul} 9$.

10. de Siqueira JV, Almeida LG, Zica BO, Brum IB, Barceló A, de Siqueira Galil AG. Impact of obesity on hospitalizations and mortality, due to COVID-19: a systematic review. Obesity research \& clinical practice. 2020 Jul 23.

11. Rivera ED, Coffey JC, Walsh D, Ehrenpreis ED. The mesentery, systemic inflammation, and Crohn's disease. Inflammatory bowel diseases. 2019 Jan 10;25(2):226-34.

12. Murphy B, Bhattacharya R, Mukherjee P. Hydrogen sulfide signaling in mitochondria and disease. The FASEB Journal. 2019 Dec;33(12):13098-125.

13. Paul BD, Snyder SH, Kashfi K. Effects of hydrogen sulfide on mitochondrial function and cellular bioenergetics. Redox Biology. 2021 Jan 1;38:101772.

14. Picca A, Lezza AMS, Leeuwenburgh C, Pesce V, Calvani R, Landi F, Bernabei R, Marzetti E. Fueling Inflamm-Aging through Mitochondrial Dysfunction: Mechanisms and Molecular Targets. Int $\mathrm{J}$ Mol Sci. 2017 Apr 28;18(5):933. doi: 10.3390/ijms18050933. PMID: 28452964; PMCID: PMC5454846.

15. Kashfi K. Anti-cancer activity of new designer hydrogen sulfide-donating hybrids. Antioxidants \& redox signaling. 2014 Feb 10;20(5):831-46.

16. Sestito S, Nesi G, Pi R, Macchia M, Rapposelli S. Hydrogen sulfide: a worthwhile tool in the design of new multitarget drugs. Frontiers in chemistry. 2017 Sep 27;5:72.

17. Citi V, Martelli A, Brancaleone V, Brogi S, Gojon G, Montanaro R, Morales G, Testai L, Calderone V. Antiinflammatory and antiviral roles of hydrogen sulfide: Rationale for considering H2S donors in COVID-19 therapy. British journal of pharmacology. 2020 Nov;177(21):4931-41.

18. Mao R, Kurada S, Gordon IO, Baker ME, Gandhi N, McDonald C, Coffey JC, Rieder F. The mesenteric fat and intestinal muscle interface: creeping fat influencing stricture formation in Crohn's disease. Inflammatory bowel diseases. 2019 Feb 21;25(3):421-6.

19. Bezpalko L, Gavrilyuk O, Zayachkivska O. Inflammatory response in visceral fat tissue and liver is prenatally programmed: experimental research. J Physiol Pharmacol. 2015 Feb 1;66(1):57-64.

20. Takagi $\mathrm{K}$, Okabe $\mathrm{S}$. The effects of drugs on the production and recovery processes of the stress ulcer. The Japanese Journal of Pharmacology. 1968 Mar 1;18(1):9-18.

21. Revenko O, Zaichko N, Wallace J, Zayachkivska O. Hydrogen sulfide system attenuates injury by hyperglycemia and stress: role of mesenteric adipocytes in aged animals. Proceeding of the Shevchenko Scientific Society. Medical Sciences. 2018 Dec 28;54(2):115-24.

22. Pavlovskiy Y, Yashchenko A, Zayachkivska O. H2S Donors Reverse Age-Related Gastric Malfunction Impaired Due to Fructose-Induced Injury via CBS, CSE, and TST Expression. Frontiers in Pharmacology. 2020 Jul 24;11:1134.

23. Stipanuk M, Beck P. Characterization of the enzymic capacity for cysteine desulphhydration in liver and kidney of the rat. Biochemical Journal. 1982 Aug 15;206(2):267-77.

24. Kredel LI, Siegmund B. Adipose-tissue and intestinal inflammation-visceral obesity and creeping fat. Frontiers in immunology. 2014 Sep 24;5:462.

25. Li XH, Feng ST, Cao QH, Coffey JC, Baker ME, Huang L, Fang ZN, Qiu Y, Lu BL, Chen ZH, Li Y. Degree of Creeping Fat Assessed by CT Enterography is Associated with Intestinal Fibrotic Stricture in Patients with Crohn's Disease: A Potentially Novel Mesenteric Creeping Fat Index. Journal of Crohn's and Colitis. 2021 Jan 7. 
26. Seifarth C, Hering NA, Arndt M, Lehmann KS, Stroux A, Weixler B, Kreis ME. Increased proinflammatory cytokines in mesenteric fat in major surgery and Crohn disease. Surgery. 2021 Jan 8.

27. Caputo T, Gilardi F, Desvergne B. From chronic overnutrition to metaflammation and insulin resistance: adipose tissue and liver contributions. FEBS letters. 2017 Oct;591(19):3061-88.

28. Akoumianakis I, Tarun A, Antoniades C. Perivascular adipose tissue as a regulator of vascular disease pathogenesis: identifying novel therapeutic targets. British journal of pharmacology. 2017 Oct; 174(20):3411-24.

29. Zhu L, Yang B, Ma D, Wang L, Duan W. Hydrogen Sulfide, Adipose Tissue and Diabetes Mellitus. Diabetes, Metabolic Syndrome and Obesity: Targets and Therapy. 2020;13:1873.

30. Jensen AR, Drucker NA, Khaneki S, Ferkowicz MJ, Yoder MC, DeLeon ER, Olson KR, Markel TA. Hydrogen sulfide: a potential novel therapy for the treatment of ischemia. Shock: Injury, Inflammation, and Sepsis: Laboratory and Clinical Approaches. 2017 Nov 1;48(5):511-24.

31. Sehajpal S, Prasad DN, Singh RK. Prodrugs of non-steroidal anti-inflammatory drugs (NSAIDs): a long march towards synthesis of safer NSAIDs. Mini reviews in medicinal chemistry. 2018 Aug 1;18(14): 1199-219.

32. Wallace JL, Nagy P, Feener TD, Allain T, Ditrói T, Vaughan DJ, Muscara MN, De Nucci G, Buret AG. A proof-of-concept, Phase 2 clinical trial of the gastrointestinal safety of a hydrogen sulfide-releasing antiinflammatory drug. British journal of pharmacology. 2020 Feb;177(4):769-77.

33. Katsouda A, Szabo C, Papapetropoulos A. Reduced adipose tissue H2S in obesity. Pharmacological research. 2018 Feb 1;128:190-9.

34. Comas F, Latorre J, Ortega F, Arnoriaga Rodríguez M, Kern M, Lluch A, Ricart W, Blüher M, Gotor C, Romero LC, Fernández-Real JM. Activation of endogenous H2S biosynthesis or supplementation with exogenous $\mathrm{H} 2 \mathrm{~S}$ enhances adipose tissue adipogenesis and preserves adipocyte physiology in humans. Antioxidants \& Redox Signaling. 2021 Mar 11.

35. Pinnick KE, Hodson L. Challenging metabolic tissues with fructose: tissue-specific and sex-specific responses. The Journal of Physiology. 2019 Jul;597(14):3527-37. 